\title{
SISTEM INFORMASI MONITORING KESEHATAN MASYARAKAT BERBASIS WEB MENGGUNAKAN METODE UNIFED MODELLING LANGUAGE
}

\author{
Yogi Isro' Mukti \\ ${ }^{1}$ Program Studi Teknik Informatika, Sekolah Tinggi Teknologi Pagar Alam \\ Sekolah Tinggi Teknologi Pagar Alam, Jln. Masik Siagim No. 75 Simpang Mbacang \\ e-mail: *yogie.isro.mukti@sttpagaralam.ac.id
}

\begin{abstract}
Abstrak
Gerakan masyarkat sehat bebas dari sakit merupakan program yang terus ditingkatkan mulai dari pemerintah pusat sampai dengan daerah. Salah satunya melalui sosialisasi pentingnya hidup sehat, dengan cara mengetahui tentang informasi penyakit di daerah masing-masing. Penelitian ini bertujuan untuk menyedia sistem informasi monitoring kesehatan masyarkat berbasis web, guna mengetahui sebaran penyakit yang sedang berkembang di masyarakat seperti pneumonia atau radang paru-paru. Metode pengembangan sistem yang digunakan adalah web engineering, dengan perancangan menggunakan Unifed Modelling Language (UML), dengan menggunakan bahasam pemrograman PHP dan database MySQL
\end{abstract}

Kata kunci — Sistem Informasi, monitoring kesehatan, Pneunomia, web

\section{Abstract}

The healthy community movement free of pain is a program that continues to be improved starting from the central government to the regions. One of them is through socializing the importance of healthy living, by knowing about disease information in their respective regions. This study aims to provide a web-based community health monitoring information system, to determine the distribution of developing diseases in the community such as pneumonia or pneumonia. The system development method used is web engineering, by designing using Unifed Modeling Language (UML), by using PHP programming and MySQL databases.

Keywords - Information system, health monitoring, pneumonia, web

\section{PENDAHULUAN}

Isu tentang penyakit merupakan bukan hal baru lagi, tingginya aktivitas rumah sakit dalama menangani berbagai penyakit merupakan salah satu indikator, tentang tingginya tingkat penyakit yang diderita, mulai dari penyakit yang ringan hingga penyakit berat. padahal Kesehatan masyarakat merupakan modal pokok dalam rangka pertumbuhan dan kehidupan suatu bangsa, untuk mewujudkan hal ini secara optimal terus diupayakan kesehatan. Pembangunan kesehatan pada masyarakat merupakan bagian integral dari pembangunan nasional yang dicanangkan, yang bertujuan meningkatkan kesadaran, kemauan dan kemauan hidup sehat bagi setiap individu agar terwujud derajat kesehatan yang optimal. Berbagai cara dilakukan dalam meningkatkan kesahatan pada masyarakat, mulai dari banyaknya rumah sakit yang dibangun, puskesmas pada tiap kecamatan dan banyaknya rekrutmen dokter yang berkualitas, dalam rangka meningkatkan kesehatan bangsa.

Berbagai cara terus diupayakan, mulai dari tingkat Pendidikan Anak Usia Dini (PAUD), sampai dengan tingkat Perguruan Tinggi terus diupayakan pentingnya 
kesehatan pada masyarkat. Mengingat pentinganya kesehatan tersebut.

Salah satu hal dalam mewujudkan derajat kesehatan masyarakat adalah dengan memanfaatkan teknologi informasi, sebagai sarana dalam mengetahui berkenaan dengan informasi mulai dari penyakit yang ada di masyarakat, sebarannya sampai dengan cara penanggulanngan terkait dengan penyakit tersebut. Sehingga masyarakat bisa mengatisipasi jika wabah penyakit mulai meningkat, serta dapat meningkatkan kewaspadaan terhadap serangan penyakit seperti pneumonia (radang paru-paru), yang merupakan salah satu jenis penyakit yang banyak diderita oleh masyarakat yang disebabkan oleh banyak. Untuk itu perlu adanya sistem pemantauan kesehatan yang mampu memberikan solusi dalam penanganan sebaran penyakit. Metode pengembangan sistem yang digunakan adalah web engineering, dengan perancangan menggunakan Unifed Modelling Language (UML), dengan menggunakan bahasam pemrograman PHP dan database MySQL

\section{TINJAUAN PUSTAKA}

Guna mengimplementasikan penelitian ini didukung dengan teori-teori agar penelitian yang dilakukan sesuai dengan yang direncanakan

\subsection{Sistem Informasi}

Defenisi tentang sistem informasi sudah banyak sekali yang menjelaskan. Seperti yang dikemukakan oleh Ward dan Peppard mendefenisiskan Sistem informasi sebagai kegiatan memanfaatkan teknologi, mengumpulkan, memproses, menyimpan, menggunakan dan menyebarkan informasi.

Sedangkan Loudan dalam bukunya mengatakan Sistem informasi sebagai seperangkat komponen yang saling berhubungan yang berfungsi mengumpulkan, memproses, menyimpan, dan mendistribusikan informasi untuk mendukung pembuatan keputusan dan pengawasan dalam organisasi. [1]

Sistem informasi berbasis komputer merupakan sekelompok perangkat keras dan perangkat lunak yang dirancang untuk mengubah data menjadi informasi yang bermanfaat. Penggunaan perangkat keras dan perangkat lunak tersebut dimaksudkan untuk menghasilkan informasi secara cepat dan akurat [1]

\subsection{Monitoring}

Monitoring sendiri merupakan kegiatan pemantauan sebuah objek atau pengawasan terhadap sesuatu guna untuk menunjang tujuan sebuah organisasi.

Monitoring sendiri dalam bahasa indonesia dikenal dengan istilah pemantauan. Monitoring merupakan sebuah kegiatan untuk menjamin akan tercapainya semua tujuan organisasi dan manajemen. [2]

Dalam kesempatan lain monitoring juga didefinisikan sebagai langkah untuk mengkaji apakah kegiatan yang dilaksanakan telah sesuai dengan rencana, mengidentifikasi masalah yang timbul agar langsung dapat diatasi, melakukan penilaian apakah pola kerja dan manajemen yang digunakan sudah tepat mencapai tujuan, mengetahui kaitan antara kegiatan dengan tujuan untuk memperoleh ukuran kemajuan. [2]

\subsection{Kesehatan Masyarakat}

Dikutip dari bukunya Endang

Purwoastuti mengatakan bahawa Kesehatan masyarakat (public helth) menurut Winslow, adalah ilmu dan seni mencegah penyakit, memperpanjang hidup dan meningkatkan kesehatan melalui "usaha-usaha pengorganisasian penyakit-penyakit menular, pendidikan untuk kebersihan perorangan untuk diagnosis dini dan pengobatan, pengembangan rekayasa sosial untuk menjamin setiap orang terpenuhi 
kebutuhan hidup yang layak dalam memelihara kesehatannya. Disiplin ilmu yang mendasari kesehatan masayarakat antara lain, mencakup : ilmu biologi, ilmu kedokteran, ilmu kimia, fisika,ilmu lingkungan, sosiologi, antropologi ( ilmu yang mempelajari budaya pada masyarakat), psikologi, ilmu pendidikan. Oleh karena itu ilmu kesehatan masyarakat merupakan ilmu yang multidisiplin. [3]

\subsection{Peneumonia}

Peneumonia dalam Bahasa indoensia dikenal dengan penyakit Radang Paru-Paru, yang merupakan sebuah penyakit pada paruparu di mana pulmonaryalveolus (alveoli) yang bertanggung jawab menyerap oksigen dari atmosfer meradang dan terisi oleh cairan. Radang paru-paru disebabkan oleh beberapa penyebab, termasuk infeksi dari bakteria, virus, jamur, atau pasilan. [4]

Penyebab radang paru-paru sendiri banyak sekali, seperti polusi udara. Penyakit ini banyak sekali diderita oleh masyarkat sehingga perlu dilihat sebaraannya.

\subsection{Website}

Agar sistem informasi yang dibangun ini bisa dikases oleh masyarakat banyak, khususnya di wilayah sekitar puskesmas Sidorejo maka sistem yang dibangun ini berbasiskan web. Web yang merupakan singatan dari Website diartikan sekumpulan halaman yang terdiri dari beberapa laman yang berisi informasi dalam bentuk data digital baik berupa text, gambar, vidio, audio, dan animasi lainnya yang disediakan melalui jalur koneksi internet. Lebih jelasnya, website merupakan halamanhalaman yang berisi informasi yang ditampilkan oleh browser seperti mozilla ferifox, google chrome atau lainnya. [5]

\subsection{Web Server}

Menurut (Nugroho, 2004) Web Server adalah sebuah bentuk server yang khusus digunakan untuk menyimpan halaman website atau homepage. Dengan kata lain webserver merupakan bentuk server yang bisa dipanggil kapan pun oleh client. [2]

Web Server merupakan software yang berfungsi untuk menerima permintaan data dari browser, permintaan data tersebut kemudian di olah dan dikirim kembali ke browser dalam bentuk dokumen HTML. [6]

\subsection{PHP}

Dalam membangu sistem informasi ini digunakan Bahasa disisi server yang cepat dan handal yakni menggunakan Bahasa pemrograman PHP singkatan dari Hypertext Preprocessor yang merupakan server-side programing, yaitu bahasa pemrograman yang diproses di sisi server. Fungsi utama PHP dalam membangun website adalah untuk melakukan ke pengolahan data pada database. Data website akan dimasukkan ke database, diedit, dihapus, dan ditampilkan pada website yang diatur oleh PHP. [7]

PHP adalah bahasa pemrograman script server-side yang didesain untuk pengembangan web. Selain itu, PHP juga bisa digunakan sebagai bahasa pemrograman umum. PHP dikembangkan pada tahun 1995 oleh Rasmus Lerdrof, dan sekarang dikelola oleh The PHP Group. Situs situs resmi PHP beralamat di http://www.php.net. PHP disebut bahasa pemrograman server side karena PHP diproses pada komputer server. Hal ini berbeda dibandingkan dengan bahasa pemrograman client-side seperti javaScript yang diproses pada web browser (client). [8]

\subsection{Bootstrap}

Bootstrap merupakan salah satu Framework CSS yang sangat popular di kalangan pencinta pemrograman website. Dengan bootstrap, desain website tidak dibuat dari nol, sehingga proses desain website lebih cepat dan mudah. Bahkan 
tanpa kita membuat skrip CSS sedikit pun, kita sudah dapat membuat desain website yang bagus. [7]

\subsection{CSS}

Agar tampilan sistem informasi yang dibangun sesuai dengan kebutuhan pengguna, salah satu yang dilkukan adalah dengan mempercantik tampilan sistem dengan CSS. CSS (Cascading Style Sheets) merupakan bahasa pemrograman web untuk mengendalikan komponen pada sebuah web sehingga lebih terstruktur. CSS lebih cenderung pada style, seperti ukuran gambar, warna teks dan tabel, ukuran dan warna border, warna hyperlink dan mouse over, spasi antar paragraf, antar teks, margin kiri, kanan, atas, bawah, dan parameter lain. [9]

\subsection{UML (Unifed Modelling Languange) \\ Untuk menggabmarkan bagaimana} sebuah sistem dibangun mulai dari awal hingga selesai, diperlukan sebuah pemodelan yakni dengan menggunakan UM. Banyak aplikasi yang dibangun menggunakan pemdoelan dengan metode UML ini. Unified Modelling Language (UML) sendiri merupakan salah standar bahasa yang banyak digunakan di dunia industri untuk mendefinisikan requirement, membuat analisis \& desain, serta menggambarkan arsitektur dalam pemrograman berorientasi objek. [10]

\section{METODOLOGI PENELITIAN}

\subsection{Sistem yang Berjalan}

Sistem yang berjalan merupakan penggambaran dari sistem yang ada, dengan melakukan pemodelan terhadap sistem yang berjalan ini bisa memudahkan dalam pembangunan sistem selanjutnya. Dalam hal ini adalah proses monitoring penyakit yang dilakukan pada puskesmas. Dimulai dari Pengelola atau admin mengelola data laporan dengan melihat data laporan pasien dan mengelompokan sesuai dengan jenis penyakit yang diderita. Kemudian melaporkan hasil data yang dikelola kepada kasubag. Sekemanya bisa dilihat pada gambar berikut :

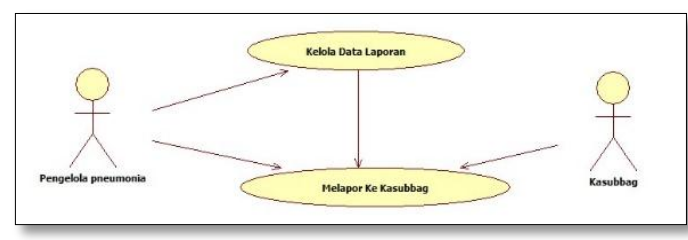

Gambar 1. Analisa Sistem Yang Sedang Berjalan

\subsection{Sistem yang Diusulkan}

Sistem yang bertujuan untuk mempermudah bagian pengelolah penyakit Pneumonia dalam memonitoring kesehatan masyarakat pada Puskesmas Sidorejo Kota Pagar Alam. Cara kerjanya yakni pengelola memasukan data pasien kedalam sistem, kemudian sistem akan mengelompokan pasien berdasarakan penyakit yang diderita dan membuat laporan otomatis sehingga proses pengelompokan lebih cepat terutama dalam pembuatan laporan dan kasubag sendiri bisa langsung memantau sebaran penyakit yang ada di wilayahnya, sekemanya bisa dilihat pada gambar berikut :

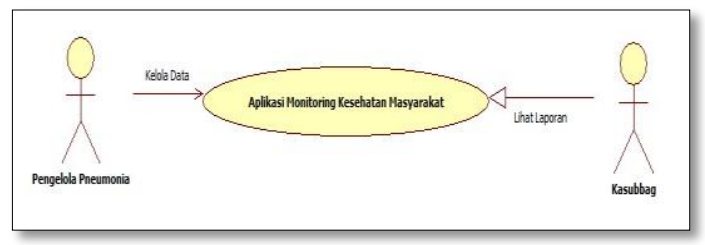

Gambar 2. Analisa Sistem Yang Diusulkan

\subsection{Metode pengembangan sistem}

Agar sistem yang dibangun berjalan sesuai dengan perencanaan maka digunakan metode pengembangan sistem yang sesuai dengan kebutuhan. Metode pengembangan sendiri adalah menyusun suatu sistem yang baru untuk menggantikan sistem yang lama 
secara keseluruhan atau memperbaiki sistem yang telah berjalan. Dalam pengembangan sistem ini metode yang digunakan menggunakan Web Engineering, karena metode ini memberikan ide kepada pengembang maupun user tentang sistem akzsan berfungsi dan akan di kembangkan.

[11]

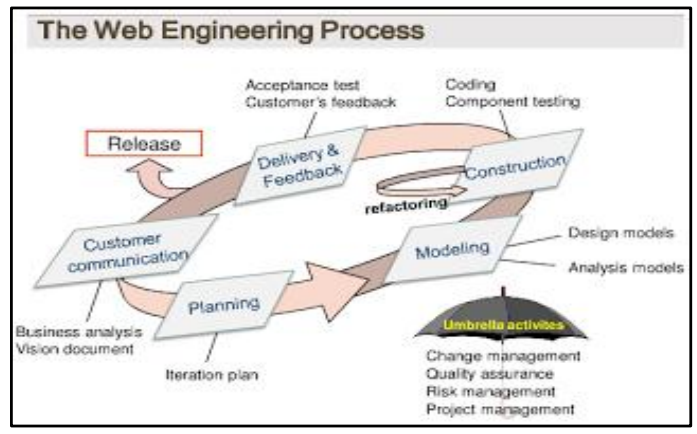

Gambar 3. Tahapan Web Engineering

\subsection{Rancangan yang diusulkan}

Use Case Diagram Rancang Bangun Aplikasi Monitoring Kesehatan Masyarakat pada Puskesmas Sidorejo Kota Pagar Alam menggambarkan interaksi antar aktor dengan sistem yang dibuat. Dengan use case ini dapat diketahui proses yang terjadi pada aktivitas yang berjalan. Berikut adalah rancangan use case diagram Rancang Bangun Aplikasi Monitoring Kesehatan Masyarakat Pada Puskesmas Sidorejo Kota Pagar Alam, yaitu Dapat dilihat pada Gambar dibawah ini:

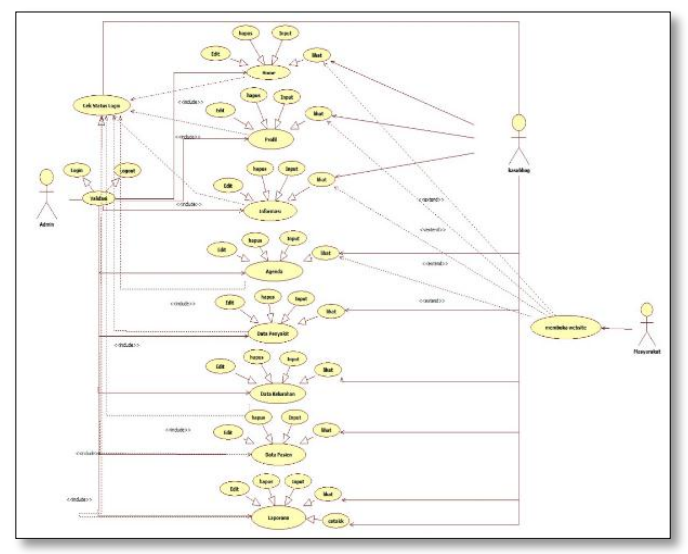

Gambar 4. Use Case Diagram Rancang Bangun Aplikasi

\subsection{Activity Diagram Masyarakat}

Activity ini menggambarkan aktifitas yang terjadi pada masyarakat terhadap sistem dimana masyarakat bisa membuka sistem dan melihat informasi tentang sebaran penyakit yang ada di wilayahnya.

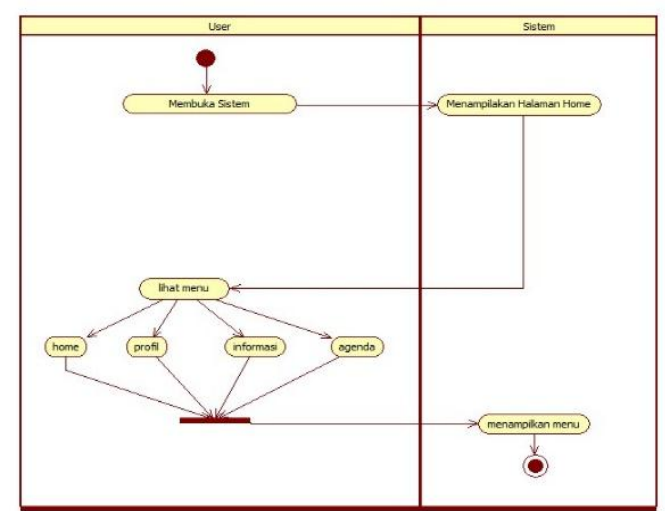

Gambar 5. Activity Diagram Masyarakat

\subsection{Sequence Diagram Masyarakat}

Pada sequence diagram digambarkan pengguna bisa membuka halaman website dan sistem kesehatan masyarakat kemudian pengguna memilih menu yang akan digunakan selanjutnya sistem akan menampilkan halaman yang dipilih sesuai dengan kebutuhan pengguna untuk lebih jelasnya bisa dilihat pada gambar sequence diagram berikut :

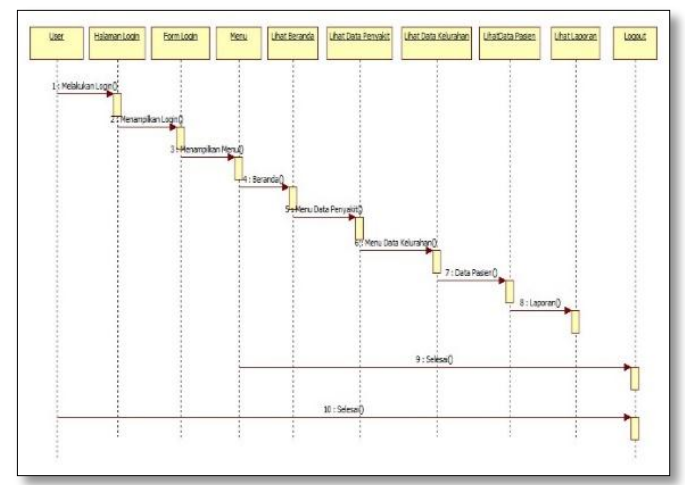

Gambar 6. Squency Diagram

\subsection{Class Diagram}

Class diagram memperlihatkan deskripsi dan struktur class, package dan 
obyek beserta hubunganya satu sama lain. Obyek merupakan hasil dari sebuah instasiasi dari sebuah class. Adapun class yang dibangun terdiri dari beberapa tabel yang saling berkaitan mulai dari tabel pasien, tabel penyakit, tabel keluarahan, tabel informasi, dan tabel pengguna.

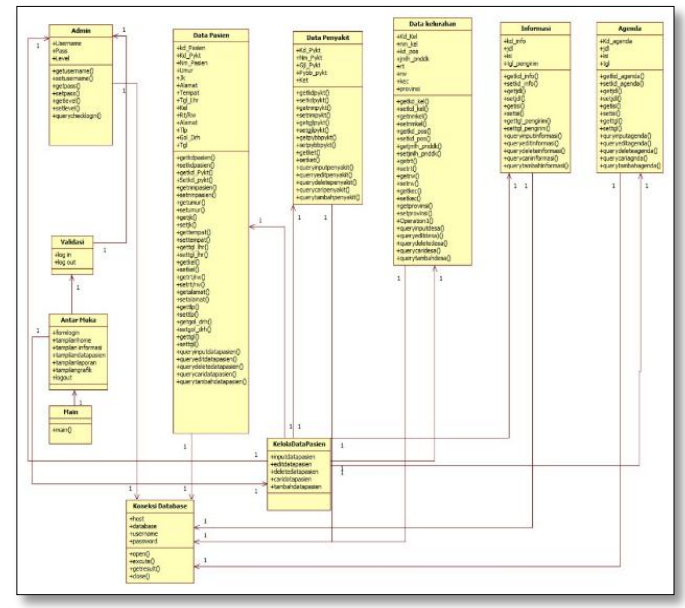

Gambar 7. Class Diagram

\section{HASIL DAN PEMBAHASAN}

\subsection{Hasil}

Dari penelitian yang dilakukan, maka dihasilkan sebuah Sistem Informasi Monitoring Kesehatan Masyarakat Berbasis Web ini. Sistem informasi ini di bangun dengan menggunakan bahasa pemrograman PHP yang mendukung pemrograman berorientasi objek. Selain itu dalam pembuatannya juga memanfaatkan MySQL sebagai database atau penyimpanan datanya. Metode pengumpulaan data yang peneliti gunakan dalam penelitian ini berupa Observasi, Wawancara, Studi Pustaka, sedangkan metode pengembangan rancang bangun yang digunakan yaitu metode $W e b$ Engineering. Dalam metode ini terdiri dari lima tahapan atau metode berupa customer comunication, plaining, modeling, construction, dan deployment.

Pada sistem ini terdapat beberapa menu utama yang memiliki fungsi sesuai dengan kebutuhan dari pengguna yang telah ditentukan pada saat perancangan sebelumnya. Rancang bangun aplikasi monitoring kesehatan masyarakat ini terdiri dari beberapa menu diantaranya menu home, profil, informasi, agenda, sebaran penyakit, data penyakit, data kelurahan, data pasien, laporan perbulan, dan laporan pertahun kesehatan masyarakat pada penyakit pneumonia saja.

\subsection{Pembahasan}

Berikut ini adalah pembahasan dari hasil uji coba atau testing Sistem Informasi Monitoring Kesehatan Masyarakat Berbasis Web. Sesuai dengan rancangan yang dibangun, sistem ini berjalan sesuai dengan yang diharapkan mulai dari rancangan sistem, rancangan antar muka dan sudah dilkaukan uji coba berikut hasil dari tampilan sistem informasi monitoring kesehatan yang dibangun.

\section{Desain Halaman User}

Halaman Menu Utama Merupakan halaman awal yang ditampilkan setelah user (masyarakat) membuka website

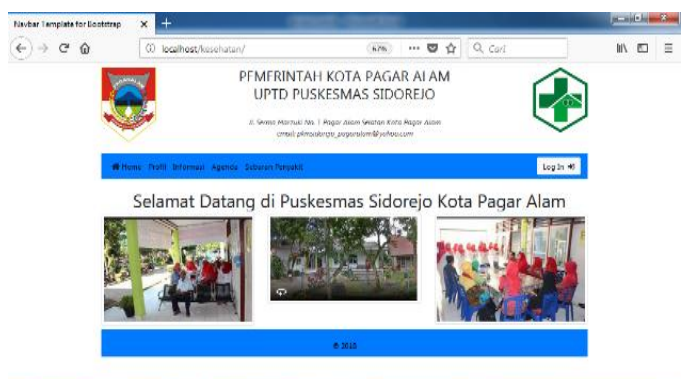

Gambar 8. Tampilan Halaman Menu Utama

\section{Profile}

Tampilan halaman menu profil ini merupakan halaman informasi untuk melihat visi\&misi, sejarah puskesmas sidorejo dan struktur organisasi Puskesmas Sidorejo kota Pagar Alam. Ketika web dibuka maka halaman profil akan langsung tampil 


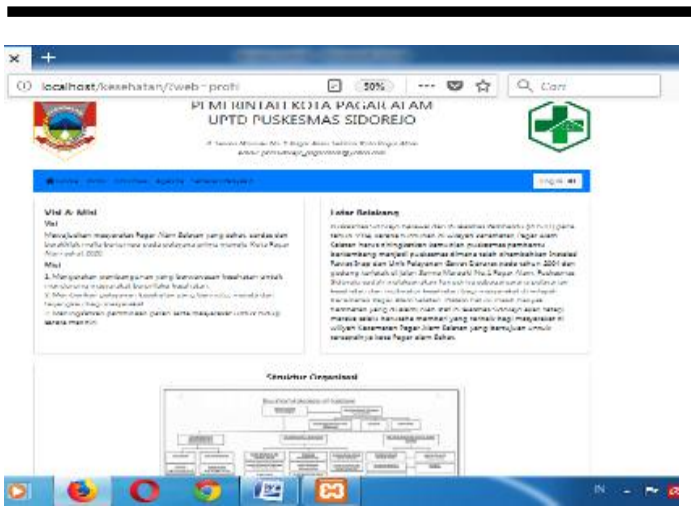

Gambar 9. Tampilan Halaman Menu Profil

3 Tampilan Halaman Informasi

Tampilan halaman menu informasi ini user dapat melihat informasi apa saja yang sudah diinputkan oleh admin sehingga user dapat mengetahuinya. Dari halaman ini masyarkat bisa mengetahui informasi yang ada di puskesmas, seperti informasi tentang penyakit, kesehatan, program-program baru yang ada pada puskesmas

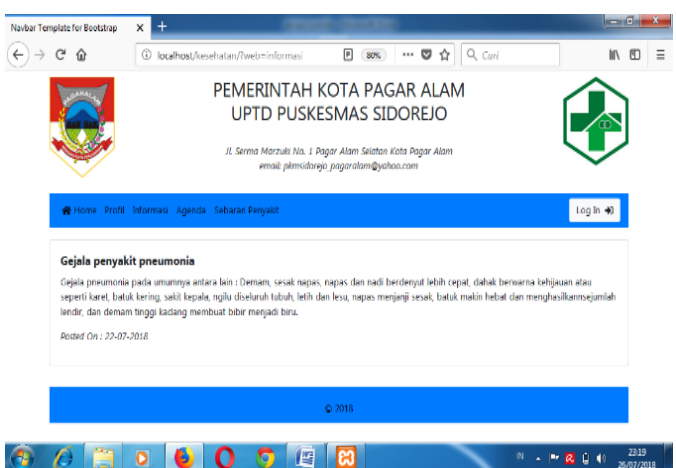

Gambar 10. Tampilan Halaman Menu Informasi

4 Tampilan Halaman Sebaran Penyakit

Tampilan halaman sebaran penyakit merupakan halaman user untuk melihat atau memantau perkembangan grafik dari penyakit pneumonia setiap bulannya di Puskesmas Sidorejo kota Pagar Alam.

Pada halaman inilah masyarakat bisa mengetahui tentang sebaran-penyakit pneumonia / radang paru-paru

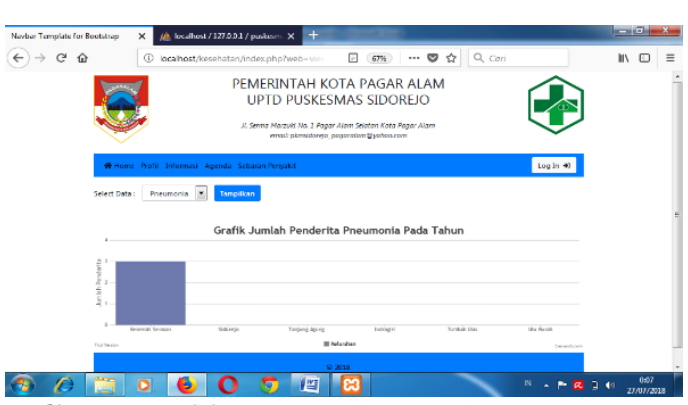

Gambar 11. Tampilan Halaman Menu Sebaran Penyakit

5 Laporan Sebaran Penyakit

Berikut bentuk dari laporan sebaran penyakit pneumonia yang di tampilkan dalam system informasi.

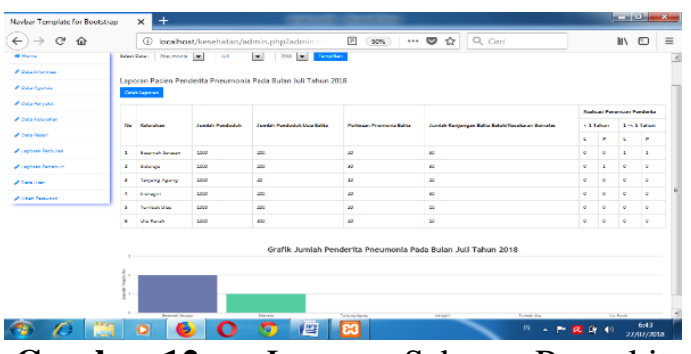

Gambar 12. Laporan Sebaran Penyakit

\section{KESIMPULAN}

Adapun dalam penelitian ini disimpulkan sebagai berikut :

1. Telah dihasilkan sistem informasi monitoring kesehatan masyarakat berbasis web.

2. Dalam desain sistem ini menggunakan Unifed Modelling Language (UML)

3. Menghasilkan informasi tentang sebaran penyakit yang ada di sekitar wilayah puskesmas sidorejo

\section{SARAN}

Agar sistem yang dibangun menjadi lebih baik lagi maka peneliti menyarakankan

1. Pengembangan kedepan bisa menggunakan framework PHP Seperti, codeigniter, yii, dll

2. Mengingat penyakit yang di monitoring baru satu, kedepannya bisa ditambahkan lagi seperti demam berdarah, dan penyakit menular 
lainnya, guna memberikan informasi bagi masyarakat.

3. Sistem yang dibangun ini hendaknya bisa dimaksimalkan dan dioptimalkan, karena berdampak positif terhadap kesehatan masyarakat

\section{DAFTAR PUSTAKA}

[1] K. Laudon, "Environment and Institutional Models of Systems Development," in Environment and Institutional Models of Systems Development, Commucation of the ACM, 1985, p. 28.

[2] N. Oktaviani, "S.kom," Rancang Bangun Website Smp Azhari Palembang, 2015.

[3] S. P. A. Th. Endang purwoastuti, "S. Pd, APP," Yogyakarta, PUSTAKABARUPRESS, 2015, p. 7.

[4] M. Yunus, "S.kom," aplikasi sistem pendukung keputusan diagnosa penyakit paru-paru dengan metode forward chaining.

[5] A. Rohi, "S. Kom," Jakarta, PT. Elex Media Komputindo, 2015.

[6] A. Junaidi, Modul Pembelajaran Wordpess dan Jommla, Bandung: Teknik infromatika, 2010.

[7] R. Abdulah, Web Programming Is Easy, Jakarta: Pt Elex Media Kompindo, 2015.

[8] H. Agusvanto, "Pendidikan teknologi dan kejuruan," Sistem informasi inventori gudang untuk mengontrol persedian barang pada gudang studi kasus , 2017.

[9] M. Tohirudin, pintar membuat web dan joomla, Jakarta, 2011.

[10] A. Rosa, in Rekaya perangkat lunak, Bandung, BI- Obses, 2015.

[11] Presman, 2010. 